\title{
A Critical Review of Criteria Used For the Selection of Pharmaceuticals and Personal Care Products in Different Environmental Matrices
}

\author{
Jessica Rodrigues Pires da Silva ${ }^{1 *}$, Cristiano Piacsek Borges ${ }^{1}$ and Fabiana Valéria da Fonseca ${ }^{2}$ \\ ${ }^{1}$ Alberto Luiz Coimbra Institute of Posgraduation and Research in Engineering (COPPE), Federal University of \\ Rio de Janeiro, Brazil. \\ ${ }^{2}$ School of Chemistry. Federal University of Rio de Janeiro, Brazil. \\ Email: jrsilva@peq.coppe.ufrj.br
}

\begin{abstract}
Pharmaceuticals and personal care products (PPCPs) are increasingly gaining attention in the context of emerging pollutants, and therefore deserve particular attention regarding criteria for their consideration in scientific research. This article presents a review of these criteria, concluding that one of the most common is selecting PPCPs that have already been previously cited in literature. This can create a biased selection because it ignores the possibility that additional, but previously unreported compounds that may also play important roles from an environmental point of view. There is an impending necessity to broaden representativeness of PPCPs in studies before they start to be regulated. Some recommendations for that were presented, the main one being to cross data from PPCPs most consumed by the population with the frequency of citing of these PPCPs in scientific databases, giving priority in research to compounds positioned as of high consumption but with low number of citations in environmental studies. Such efforts will require big data analyzes.
\end{abstract}

Keywords: environment, pharmaceuticals, prioritization, selection, water, wastewater.

\section{Introduction}

Pharmaceutical and personal care products (PPCPs) are a class of diverse emerging environmental contaminants threatening water safety and public health [1]. They can be found in drugs, including both therapeutic and veterinary, and cosmetics in general, and contain active ingredients that have been designed to have effects on living organisms. Some classes of PPCPs include antibiotic, antidepressant, antidiabetic, antipsychotic, antihypertension, non-steroidal anti-inflammatory, artificial hormones, preservative compounds, fragrances and sunscreening agents [2].

PPCPs are present commonly in waters at trace concentrations $(\mathrm{ng} / \mathrm{L}$ to $\mu \mathrm{g} / \mathrm{L})$. Because of this low concentration, they have complicate detection and analysis procedures, which are prone to high experimental error. They are considered emerging pollutants, in a sense they were not traditionally found/detected in waters and thus not considered contaminants, but can nowadays be found in many waters entering the environment by a variety of sources: wastewater and effluent networks, improper disposal methods of waste and farm animals excretion, to name a few. In wastewater networks, the main source of PPCPs is excretion of unabsorbed drugs in urine and faeces, and other sources include flushing unused medications down the toilet and industrial discharges. PPCPs in this case are transported to wastewater treatment plants, where some can be removed in conventional treatment plants (by various mechanisms such as biodegradation, absorption and adsorption), but many cannot be removed, and are eventually discharged in surface waters, from where they can spread to groundwater and even the ocean $[3,4]$. It is well established in literature that many PPCPs can create ecotoxicological effects in aquatic organisms, even at the very low concentrations they occur at the environment.

As a result, there is a renewed interest in PPCPs elimination or reduction in the environment, and the main way to do this is to prevent the arrival of PPCPs in the waters by improving their removal at the effluent treatment plants. Particularly the class of antibiotics has been specially studied, due to the fear that the existence of residues of antibiotic in the environment can cause microbial resistance. Another widely studied class is synthetic hormones produced by the pharmaceutical industry, since these hormones are proven to be endocrine disruptors in the environment $[5,6]$. 
There is a vast literature available about removal of PPCPs from waters and wastewaters. There is also a trend in regulatory agencies from several countries to begin to regulate some PPCPs. In this sense, Switzerland became the first country in the world to regulate some PPCPs on discharges from municipal wastewater treatment plants.

It is important to discuss how to select PPCPs for analysis in environmental matrices, since there are more than 1,000 PPCPs that are synthesized and consumed and may, therefore, be expected at some degree to be present in the environment [7]. It is clear no researcher or regulator can consider not even close to this amount. A rigorous selection of which PPCPs should be selected, while ensuring representativeness, must be made. This article present some regulations up-to-date that may help guide this selection, and review strategies for selection used by various authors in environmental monitoring studies of PPCPs or in studies for removal of PPCPs from municipal wastewater. A critical analysis of these strategies is made, and some considerations are proposed to improve them.

\section{Experimental Protocol}

Regulations presented and discussed in this paper were obtained directly from the regulatory agencies' websites.

The articles considered of interest in this article are those that present environmental monitoring studies that include PPCPs, as well as those that present studies of removal of PPCPs from municipal wastewater, since this type of wastewater is the main point of entry of PPCPs in the environment and, consequently, the most studied in the literature. Originally the selection of articles of interest considered only those that clearly stated which criteria was used to select PPCPs, in order to substantiate the critical analysis of this article. However, it was observed that several articles do not mention any criteria, and this is a relevant fact. Thus, these articles were included as well.

Scientific papers of interest were compiled from the SCOPUS® and Web of Science® databases. Preselection of articles was made by searching for keywords: "pharmaceuticals" or "personal care products" or "trace organic compounds" or "micropollutants". Each of these was simultaneously associated with one of following terms "wastewater treatment", "monitoring", "environmental monitoring", "environment". Each expression (eg "pharmaceuticals" "wastewater treatment") was searched in both databases and the articles found that were of interest had their names and abstracts pre-selected in a spreadsheet. The search was repeated for all of the expressions, until the end of all possible combinations. In the case of a selected article also refers to micropollutants / trace organic compounds that are not PPCPs, it was considered only the part related to PPCPS, if any. If there were no PPCPs, the article was disregarded.

Final selection was made by separating pre-selected articles into two major groups: group 1, environmental monitoring studies that include PPCPS and group 2, advanced treatment studies to optimize the removal of PPCPs from sanitary sewage (municipal wastewater). For group 1, geographical variety was sought, and thus preference was given to one article from each location, although other aspects were also considered such as a relevant quantity of compounds sought and a sufficiently broad sampling plan. For group 2, a variety of PPCP removal technologies was sought.

Figure 1 was made considering the number of articles that explicitly mention the PPCP in the environmental context, either as wastewater treatment, monitoring study or even ecotoxicology. For this, the research was done in the SCOPUS® database using connector "AND" an "OR". As keywords, it was considered the name of the PPCP, and the following terms: "environment", "wastewater treatment", "monitoring" or "environmental monitoring", "Ecotoxicity","water toxicity","water ecotoxicity". The search expression is illustrated below:

"name of PPCP (for example estradiol)" AND "environment" OR "wastewater treatment" OR "monitoring" OR "environmental monitoring" OR "Ecotoxicity" OR "water toxicity" OR "water ecotoxicity". 


\section{Results and Discussion}

\subsection{Existing Regulations for Selection of Pharmaceuticals and Personal Care Products}

Regulations are a major guidance on which compounds to consider in scientific studies. Conversely, to get to the point where a compound is regulated, years of research into this compound are needed to demonstrate the need for its inclusion in regulation. When dealing specifically with PPCPs, science is still at the stage of accumulating relevant information, as noted for example by the existence of a list of contaminants of interest issued by the United States Environmental Protection Agency (USEPA) containing PPCPs that do not yet have a status of regulated compounds. This list has a version 4 complete, version 5 open for consultation (EPA, 2019) [8]. Table 1 lists the PPCPs found in CCL4 by EPA.

Table 1. Pharmaceuticals and personal care producs present in Contaminant Candidate List (CCL) version 4 by the United States Environmental Protection Agency (Source [8])

\begin{tabular}{lll}
\hline PPCP & Category & Comment \\
\hline 17alpha-estradiol & Pharmaceutical & Estrogenic hormone found in some pharmaceuticals. \\
Equilenin & Pharmaceutical & Estrogenic hormone used in hormone replacement therapy. \\
Equilin & Pharmaceutical & Estrogenic hormone used in hormone replacement therapy. \\
Erythromycin & Pharmaceutical & Antibiotic \\
Estradiol (17-beta estradiol) & Pharmaceutical & It is an isomer of estradiol found in some pharmaceuticals. \\
Estriol & Pharmaceutical & It is a weak estrogenic hormone used in veterinary \\
& Pharmaceutical & It is a precursor of estradiol used in veterinary and human \\
Estrone & pharmaceuticals. & \\
Ethinylestradiol & Pharmaceutical & It is an estrogenic hormone and is used in veterinary and \\
& human oral contraceptives. \\
Mestranol & Pharmaceutical & It is a precursor to ethinylestradiol used in veterinary and \\
& Phuman pharmaceuticals. \\
Norethindrone (19-Norethisterone) & Pharmaceutical & Norethindrone is a synthetic hormone used in oral \\
& & contraceptives and for hormone replacement therapy. \\
\hline
\end{tabular}

Meanwhile, in March 2019, the European Comission, recognizing this gap when addressing particularly PPCPs among micropollutants, issued a communication to stakeholders presenting its strategic approach to pharmaceuticals in the environment. This communication letter outlines several steps to be taken, including expand existing environmental monitoring and including additional potentially relevant pharmaceuticals, but mentions no methodology to do so (EC, 2019a) [9]. Certainly the issue of selecting new relevant pharmaceuticals will be very discussed in the coming months and years, and methodologies found in scientific literature should play a role to point in the right direction.

It is noteworthy that different regulatory agencies around the world already present advanced discussions or regulations for organic compounds of anthropogenic nature, referred depending on the agency as Micropollutants (MP), Persistent Organic Pollutants (POP), Persistent, Bioaccumulative and Toxic (PBT) or very Persistent and very Bio-accumulative (vPvB) compounds. In theory these terms include PPCPs, but they also cover other organic compounds of anthropogenic origin, for example, pesticides, herbicides, solvents and chemical products like Polycyclic aromatic hydrocarbon (PAH) and Volatile organic compound (VOCs).

The European Union, for example, has a document entitled Water Framework Directive (WFD) since 2000, which aims to stimulate the development of innovative, more cost effective water treatment technologies for priority pollutants and outlines steps to be taken in a variety of subjects relevant to water. In Article 16, it sets out "Strategies against pollution of water", and the foremost of these strategies was to establish a list of priority pollutants, which has been done in 2008 and amended in 2012. This list of 33 priority substances, selected from amongst those presenting a significant risk to or via the aquatic environment following procedures outlined in Article 16 of the WFD, includes pesticides, 
herbicides, solvents and several other industrial chemicals, but no PPCPs appears on this list. The full list is available online (EC, 2019b) [10].

In the United States, USEPA determines water quality standards in relation to certain substances in surface waters e.g., rivers, lakes and tidal waters, and also for wastewater discharges [11]. The substances include certain pesticides (atrazine, simazine, tributyltin1) and solvents (dichloromethane, toluene, xylene) in addition to metals, cyanide and fluoride, but again no PPCPs yet.

Supporting the possibility of future regulation, the EPA has already promulgated a method for analyzing 70 PPCPs in water, soil, sediments and biosolids matrices- the Method 1694 [12] available online. This method employs high performance liquid chromatography combined with tandem mass spectrometry (HPLC/MS/MS) using isotope dilution and internal standard quantitation techniques. No mention on priorization criteria for selecting this 70 PPCPs was included in the method, and not all PPCPs in this method were later included in CCL4.

So far, the only country in the world with legislation specifically covering PPCPs in municipal wastewaters discharges is Switzerland, where the law came into force on January 1, 2016. The legislation considers 12 target substances for monitoring on WWTP output, from which 9 are PPCPs. Table 2 lists the PPCPs present in this selection.

Table 2. Pharmaceuticals and personal care producs present in Switzerland legislation for municipal wastewater discharges (Source [13])

\begin{tabular}{lll}
\hline PPCP & Category & Class \\
\hline Amisulprid & Pharmaceutical & Antipsychotic \\
Carbamazepine & Pharmaceutical & Anticonvulsivant \\
Citalopram & Pharmaceutical & Antidepressive \\
Clarithromycin & Pharmaceutical & Antibiotic \\
Diclofenac & Pharmaceutical & Antiinflammatory non steroidal \\
Hydrochlorothiazid & Pharmaceutical & Antidiuretic \\
Metoprolol & Pharmaceutical & Beta blocker \\
Venlafaxin & Pharmaceutical & Antidepressive \\
Candesartan & Pharmaceutical & Angiotensin II Receptor Blockers (ARB) \\
Irbesartan & Pharmaceutical & Angiotensin II Receptor Blockers (ARB) \\
\hline
\end{tabular}

According the Switzerland legislation, for each sampling, the arithmetic means of the individual removal efficiency of 5 of the 12 substances has to be $80 \%$ relative to the concentration input in municipal wastewater treatment plants. In order to achieve so, these plants were upgraded with ozone and powdered activted carbon (PAC), a choise made considering existing infrastructure and operation and easiness to upgrade. The list of target PPCPs will be updated every 5 years [13]. The Swiss example will certainly be an important reference for all the other countries seeking to write their own regulations in the coming years.

\subsection{Methodologies Found in the Literature for Selection of Pharmaceuticals and Personal Care Products}

Several research groups proposed priority lists for PPCPs in the environment. Al Aukidy et al. [14] proposed a framework for the assessment of the environmental risk posed by pharmaceuticals from hospital effluents (que é classificado como esgoto sanitário) and by using it, identified pharmaceuticals of concern that might require extra management in order to reduce risk. They are: ofloxacin, 17a ethinylestradiol, erythromycin and sulfamethoxazole.

Jean et al. [15] also proposed a priorization strategy for pharmaceuticals from hospital effluents, primarily based on their bioaccumulation potential. Starting from a list of 960 substances consumed in hospitals, they established a shortlist of 70 substances considered as being potentially bioaccumulable. The use of aggravating factors - ecotoxicological and pharmacological potential and biodegradability led to the final selection of 14 priority pharmaceuticals: Amiodarone, Dextropropoxyphene, Deslcratadine, Nicardipine, Ethinylestradiol, Tamoxifen, Norgestimate, Amitriptyline, Mitotane, 
Mifepristone, Telithromycine, Ritonavir, Itraconazole and Hexetidine. The next step would be verify their bioaccumulation potential experimentally and confirm their presence in the environment.

Voogt et al. [16] developed a common priority list for Pharmaceutically active compounds (PhACs), including prescription drugs, over-the-counter medications and drugs used in hospitals, but not considering veterinary drugs. They reduced the number to a minimum of ten PPCPs of high priority, representing the minimum that should be considered in any study on pharmaceuticals in water management, not just for hospital effluents - they are Carbamazepine, Sulfamethoxazole, Diclofenac, Ibuprofen, Naproxen, Bezafibrate, Atenolol, Ciprofloxacin, Erythromycin and Gemfibrozil. Another thirty-four PPCPs were also included for consideration. A major limitation of this study is they only considered in their methodology PPCPs already mentioned in the literature, thus excluding potential relevants compounds that have not been researched yet, but should, and therefore should have been considered at some point in a priorization methodology.

Pochodylo and Helbling [17] elaborated a detailed priorization strategy to scan an urban water system in New York State, United States; similarly Busch et al. [18] developed one for European rivers, and Carsten von der Ohe [19] developed another considering pollutants under the European Water Framework Directive. Nevertheless, in those cases the strategy was not directed just for PPCP selection, but rather for micropollutants which is a more broad term and also includes also pesticides and industrial chemicals.

Tables 3 and 4 present the methodologies used by authors to select the PPCPs they studied. Table 3 illustrates results for environmental monitoring, and Table 4, for effluent treatment containing PPCPs.

Researchers should review thoroughly state-of-art literature considering their location of interest, in order to assess what is available already and which methodologies have been used to select PPCPs caseby-case. Nonetheless, from observing Tables 3 and 4, some points stand out. Most common strategy for selection is considering the most used PPCPs. This makes sense, as drugs and personal care products (PCP) of high-use / prescription should be by logic the most found in the effluents, considering the main route of entry into the environment being the elimination by human body. This hypothesis has already been successfully tested by Oosterhuis et al. [20] in a study in the Netherlands, which found high correlations between most used drugs locally and most found in effluents. It is however noteworthy that, even though all drugs are excreted partially in human faeces and urine, the percentage of this excretion may vary, as some drugs are more absorbed by the body than others. Moreover, some drugs are only excreted in metabolite forms and not as the original, parental form. That is the case for carbamazepine, acetaminophen, ibuprofen, for example [21]. Therefore using information of consumption to correlate with presence in waters has limitations.

Moreover, some authors simply do not mention their criteria for choosing PPCPs when discussing wastewater treatment. For those who do mention, common criteria other than most used PPCPs are: compounds already frequently mentioned in literature; physicochemical characteristics; or a choice for micropollutants representing different therapeutic classes. What stands out is that even with authors do mention criteria for selecting PPCPs, they seldom mention a clear methodology on how did they organize these criteria on a logical order. The majority simply stated which criteria they considered. Some exceptions that did present a well defined methodology are Karelid et al. [22], whom prioritized elements that cause more damage to the environment (they made a restriction on compounds that have proven effects on fish); and Urtiaga et al. [23] whom proposed a pre-selection and a final selection, reducing PPCPs to those present in higher concentrations.

Another important aspect is that some compounds, such as carbamazepine, diclofenac, sulfamethoxazole, ibuprofen, appear with great frequency in several studies. It is worth questioning whether so few compounds are the only PPCPs with such widespread prevalence in the world's waters since that there are so many PPCPs of great consumption in the world.

This tendency of relatively few and same compounds to occupy the attention of studies has been noted over the last decade [24]. Nonetheless, this point is seldom explictly mentioned in studies. Daughton [24] described a phenomen he called "Matthew Effect": making the decision of which target pollutant (stressors on the environment) to select based on whether they have been already been previosuly identified in studies, rather than considering the possibility that additional, but previously unreported pollutants may also play important roles in exposure. In other words, selection of targets to monitoring being biased by previously available data. 
Table 3. Literature available about PPCPs monitoring in waters worldwide and its selection methodology.

\begin{tabular}{|c|c|c|c|c|c|}
\hline Locality & $\begin{array}{l}\text { Number of } \\
\text { compounds } \\
\text { sought }\end{array}$ & About sample & PPCPs more frequently detected & Methodology to select PPCPs & Reference \\
\hline U.S.A. territory & 100 & $\begin{array}{l}74 \text { collection points, } \\
\text { surface and } \\
\text { groundwater for } \\
\text { drinking purposes }\end{array}$ & $\begin{array}{l}\text { Surface water: cholesterol, cotinine (nicotine } \\
\text { metabolite) and 1,7-dimethylxanthine } \\
\text { (caffeine metabolite). Grondwater: } \\
\text { carbamazepine, bisphenol-A, 1,7- } \\
\text { dimethylxanthine (caffeine metabolite) }\end{array}$ & $\begin{array}{l}\text { Known or suspected usage,toxicity, } \\
\text { potential hormonal activity, persistence } \\
\text { in the environment, as well as results } \\
\text { from previous studies }\end{array}$ & 31 \\
\hline New York, U.S.A. & 185 & $\begin{array}{l}4 \text { collection points of } \\
\text { hospital wastewater } \\
\text { and municipal } \\
\text { wastewater (including } \\
\text { hospital and domestic) }\end{array}$ & $\begin{array}{l}\text { Hospital wastewater: Acetaminophen, } \\
\text { caffeine, gabapentin, ibuprofen, metformin, } \\
\text { naproxen, theobromine and theophylline. } \\
\text { Municipal wastewater: acetaminophen, } \\
\text { caffeine, furosemide, gabapentin, metformin, } \\
\text { sulfamethoxazole, theobromine and } \\
\text { trimethoprim }\end{array}$ & $\begin{array}{l}\text { USEPA Method } 1694 \text { and a list of most } \\
\text { prescribed drugs in the USA }\end{array}$ & 26 \\
\hline Lausanne, Switzerland & 58 & $\begin{array}{l}3 \text { collection points, } \\
\text { raw drinking water } \\
\text { and municipal } \\
\text { wastewater }\end{array}$ & $\begin{array}{l}\text { Raw drinking water: carbamazepine, } \\
\text { gabapentin, primidone, acetaminophen, } \\
\text { norfloxacin. Municipal wastewater: } \\
\text { ibuprofen, acetaminophen, carbamazepine, } \\
\text { gabapentin, benzafibrate, iohexol, iomeprol, } \\
\text { iopromide, benzotriazole, } \\
\text { methylbenzotriazole }\end{array}$ & $\begin{array}{l}\text { Annual sales volumes of pharmaceuticals } \\
\text { (as far as available), the degree of } \\
\text { human metabolism and the estimated } \\
\text { removal in the WWTP, presence in } \\
\text { previous monitoring campaigns, direct } \\
\text { request from the Swiss Federal Office for } \\
\text { the Environment. }\end{array}$ & 32 \\
\hline Europen Union territory & 156 & $\begin{array}{l}90 \text { collection points, } \\
\text { municipal wastewater }\end{array}$ & $\begin{array}{l}\text { Acesulfane, sucralose, benzotriazoles, } \\
\text { carbamazepine, tramadol, telmisartan, } \\
\text { venlafaxine, irbesartan, fluconazole, } \\
\text { oxazepam, fexofenadine, diclofenac, } \\
\text { citalopram, codeine, bisoprolol, eprosartan, } \\
\text { trimethoprim, ciprofloxacine, } \\
\text { sulfamethoxazole, clindamycine, caffeine. }\end{array}$ & Not presented & 33 \\
\hline
\end{tabular}




\begin{tabular}{|c|c|c|c|c|c|}
\hline $\begin{array}{l}\text { Baltic Sea (Germany), } \\
\text { Northern Adriatic Sea (Italy), } \\
\text { Aegean Sea and Dardanelles } \\
\text { (Greece and Turkey), San } \\
\text { Francisco Bay (USA), Pacific } \\
\text { Ocean (USA), Mediterranean } \\
\text { Sea (Israel), and Balearic Sea } \\
\text { (Spain) }\end{array}$ & $41-53$ & 153 seawater samples & $\begin{array}{l}>50 \% \text { samples: Caffeine, paraxanthine, } \\
\text { theobromine, tolyltriazole, } 1 \mathrm{H}-\text { benzotriazole. } \\
30-50 \% \text { of samples: carbamazepine, } \\
\text { iopamidol, sulfamethoxazole, paracetamol, } \\
\text { theophylline and atenolol. } 30-50 \% \text { : } \\
\text { carbamazepine, iopamidol, sulfamethoxazole, } \\
\text { paracetamol, theophylline and atenolol }\end{array}$ & Not presented & 34 \\
\hline Umea, Sweden & 105 & $\begin{array}{l}9 \text { collection points of } \\
\text { hospital wastewater } \\
\text { and municipal } \\
\text { wastewater (including } \\
\text { hospital and domestic) }\end{array}$ & $\begin{array}{l}\text { Hospital wastewater: acetaminophen, } \\
\text { flecainide, fluconazole, ciprofloxacin, } \\
\text { ofloxacin, levofloxacin, sulfamethoxazole, } \\
\text { trimethoprim and progesterone }\end{array}$ & Not presented & 35 \\
\hline France & 52 & $\begin{array}{l}141 \text { collection points, } \\
71 \text { surface waters and } \\
70 \text { groundwater }\end{array}$ & $\begin{array}{l}\text { >70\% samples: salicylic acid (metabolic of } \\
\text { aspirin), carbamazepine; acetaminophen; } \\
\text { diclofenac; sulfamethoxazole, testosterone, } \\
\text { androstenedione and progesterone }\end{array}$ & $\begin{array}{l}\text { French consumption, predicted } \\
\text { environmental concentrations as well as } \\
\text { ecotoxicological, pharmacological and } \\
\text { physicochemical data }\end{array}$ & 36 \\
\hline São Paulo, Brazil & 11 & $\begin{array}{l}1 \text { collection point, } \\
\text { surface water }\end{array}$ & $\begin{array}{l}\text { Caffeine, acetaminophen, Atenolol, } \\
\text { Ibuprofen, Naproxen, Diclofenac, Triclosan, } \\
\text { propanolol, Carbamazepine }\end{array}$ & Not presented & 37 \\
\hline Fortaleza, Brazil & 23 & $\begin{array}{l}2 \text { collection points, } \\
\text { municipal wastewater }\end{array}$ & $\begin{array}{l}\text { Paracetamol, hydrochlorothiazide, } \\
\text { furosemide, naproxen, ibuprofen, diclofenac, } \\
\text { bezafibrate, gemfibrozil, simvastatin, } \\
\text { ketoprofen, azithromycin, bisoprolol, } \\
\text { lorazepam and paroxetine }\end{array}$ & Not presented & 38 \\
\hline Spain & 31 & $\begin{array}{l}\text { One collection point, } \\
\text { municipal wastewater }\end{array}$ & $\begin{array}{l}\text { Ibuprofen, acetaminophen, ofloxacin, } \\
\text { gemfibrozil, bezafibrate, atenolol, } \\
\text { glibenclamide, hydrochlorothiazide }\end{array}$ & Not presented & 39 \\
\hline Greece & 18 & $\begin{array}{l}8 \text { collection points, } \\
\text { municipal wastewater }\end{array}$ & $\begin{array}{l}\text { Paracetamol, caffeine, trimethoprim, } \\
\text { sulfamethoxazole, carbamazepine, diclofenac } \\
\text { and salicylic acid }\end{array}$ & $\begin{array}{l}\text { High annual consumption, previous } \\
\text { studies about their occurrence, removal } \\
\text { in wastewaters and surface waters, } \\
\text { stability and poor elimination during } \\
\text { wastewater treatment and concern } \\
\text { about their possible effects on human } \\
\text { and aquatic organisms }\end{array}$ & 40 \\
\hline
\end{tabular}




\begin{tabular}{|c|c|c|c|c|c|}
\hline Spain & 84 & $\begin{array}{l}2 \text { collection points, } 20 \\
\text { samples, municipal } \\
\text { wastewater }\end{array}$ & $\begin{array}{l}\text { 4-Aminoantipyrine, bezafibrate, diclofenac, } \\
\text { gemfibrozil, ketoprofen, naproxen and } \\
\text { venlafaxine }\end{array}$ & $\begin{array}{l}\text { Special focus to antibiotics because of } \\
\text { the possible promotion of bacterial } \\
\text { resistance }\end{array}$ & 5 \\
\hline
\end{tabular}

Table 4. Literature available about PPCPs treatment and removal in municipal wastewater and its selection methodology.

\begin{tabular}{|c|c|c|c|c|}
\hline $\begin{array}{l}\text { Technology evaluated } \\
\text { to remove PPCPs }\end{array}$ & About sample & PPCPs analyzed & Methodology to select PPCPs & Reference \\
\hline $\begin{array}{l}\text { Sequential batch } \\
\text { reactor and } \\
\text { nanofiltration }\end{array}$ & $\begin{array}{l}\text { Synthetic } \\
\text { municipal } \\
\text { wastewater }\end{array}$ & $\begin{array}{l}\text { Diclofenac, Ibuprofen, Naproxen, Carbamazepine, Dilatin, } \\
\text { Primidone,Amitriptyline, Fluoxetine, Bezafibrate, Gemfibrozil, } \\
\text { Sulfamethoxazole, Trimethoprim, Atenolol, Caffeine, } \\
\text { Diphenhydramine, Iopromide, Benzophenone }\end{array}$ & Not presented & 41 \\
\hline $\begin{array}{l}\text { Membrane bioreactor } \\
\text { and nanofiltration or } \\
\text { reverse osmosis }\end{array}$ & $\begin{array}{l}\text { synthetic } \\
\text { municipal } \\
\text { wastewater }\end{array}$ & $\begin{array}{l}\text { caffeine, atenolol, metoprolol, amoxicilin, trimethoprim, } \\
\text { sulfadimidine, sulfamethoxazole, norfloxacin, ofloxacin, } \\
\text { ciprofloxacin, lomefloxacin, enrofloxacin, oxytetracycline, } \\
\text { tetracycline, chlortetracycline, doxycycline, clarithromycin, } \\
\text { erythromycin, roxithromycin, azithromycin, carbamazepine, } \\
\text { benzhabeite, estrone, estradiol, estriol }\end{array}$ & $\begin{array}{l}\text { MPs that are found in wastewater and } \\
\text { natural waters. Physical-chemical } \\
\text { characteristics were also taken into } \\
\text { consideration. }\end{array}$ & 42 \\
\hline $\begin{array}{l}\text { Activated sludge } \\
\text { bioreactor acclimatized } \\
\text { and bioaugmented }\end{array}$ & $\begin{array}{l}\text { synthetic generic } \\
\text { high strength } \\
\text { wastewater }\end{array}$ & Carbamazepine, diclofenac and DEET & Not presented & 43 \\
\hline $\begin{array}{l}\text { Conventional sewage } \\
\text { treatment followed by } \\
\text { retention soil filter (a } \\
\text { type of constructed } \\
\text { wetland) }\end{array}$ & $\begin{array}{l}\text { sewage (municipal } \\
\text { wastewater) }\end{array}$ & $\begin{array}{l}\text { galaxolide, gabapentin, carbamazepine and its metabolite } \\
\text { carbamazepinedihydro-dihydroxy, diclofenac and its metabolite } \\
\text { 4-hydroxy-diclofenac, metformin, tmetoprolol, sotalol, } \\
\text { clarithromycin and sulfamethoxazole }\end{array}$ & Not presented & 44 \\
\hline $\begin{array}{l}\text { Powered and granular } \\
\text { activated carbon }\end{array}$ & $\begin{array}{l}\text { municipal } \\
\text { wastewater } \\
\text { previously treated } \\
\text { by biological } \\
\text { treatment }\end{array}$ & $\begin{array}{l}\text { Atenolol, Bisoprolol, Bupropion, Carbamazepine, Citalopram, } \\
\text { Clarithromycin, Clindamycin, Codeine, Diclofenac, Diltiazem, } \\
\text { Fexofenadine, Flecainide, Fluconazole, Irbesartan, memantine, } \\
\text { metoprolol, mirtazepine, oxazepam, sotalol, tramadol, } \\
\text { trimethoprm, venlafaxine }\end{array}$ & $\begin{array}{l}\text { Selection started over } 100 \text { substances that has } \\
\text { shown high potency and potential for } \\
\text { bioaccumulation in fish, and was narrowed to } \\
\text { the } 22 \text { of higher occurence at the local } \\
\text { wastewater treatment plant }\end{array}$ & 22 \\
\hline Algal treatment & $\begin{array}{l}\text { Black water or } \\
\text { urine (from } \\
\text { sewage) }\end{array}$ & $\begin{array}{l}\text { Ibuprofen, diclofenac, paracetamol, trimethoprim, metoprolol } \\
\text { and carbamazepine, estrone, estradiol and ethinylestradiol }\end{array}$ & $\begin{array}{l}\text { Representant of different therapeutic groups, } \\
\text { are widely used in large quantities in Europe } \\
\text { and North America. }\end{array}$ & 45 \\
\hline
\end{tabular}




\begin{tabular}{|c|c|c|c|c|}
\hline $\begin{array}{l}\text { Osmotic bioreactor with } \\
\text { reverse osmosis and } \\
\text { conventional membrane } \\
\text { bioreactor with reverse } \\
\text { osmosis }\end{array}$ & $\begin{array}{l}\text { Synthetic } \\
\text { wastewater }\end{array}$ & $\begin{array}{l}\text { Salicylic acid, naproxen, metronidazole, ibuprofen, primidone, } \\
\text { diclofenac, gemfibrozil, carbamazepine, DEET, estriol, } \\
\text { Amitriptyline, benzophenone, oxybenzone, estrone, } \\
\text { ethinylestradiol, estradiol, triclosan, B-Estradiol-17-acetate }\end{array}$ & $\begin{array}{l}\text { PPCPs selected to represent four major } \\
\text { groups of micropollutants - endocrine } \\
\text { disrupting compounds, pharmaceutical and } \\
\text { personal care products, industrial chemicals, } \\
\text { and pesticides - that occur ubiquitously in } \\
\text { municipal wastewater. }\end{array}$ & 46 \\
\hline $\begin{array}{l}\text { Powdered activated } \\
\text { carbon }\end{array}$ & $\begin{array}{l}\text { municipal } \\
\text { wastewater } \\
\text { previously treated } \\
\text { by biological } \\
\text { treatment }\end{array}$ & $\begin{array}{l}\text { Ketoprofen, naproxen, paracetamol, ibuprofen, diclofenac, } \\
\text { sulfamethoxazole, ofloxacin, ciprofloxacin, trimethoprim, } \\
\text { metronidazole, roxithromycin, norfloxacin, erythromycin, } \\
\text { sulfadimerazine, sulfadiazine, sulfameter, sulfathiazole, atenolol, } \\
\text { propranolol, carbamazepine, oxazepam, lorazepam, bezafibrate, } \\
\text { fenofibrate, estrone, testosterone }\end{array}$ & Not presented & 47 \\
\hline $\begin{array}{l}\text { Ultrafiltration and } \\
\text { reverse osmosis }\end{array}$ & $\begin{array}{l}\text { municipal } \\
\text { wastewater } \\
\text { previously treated } \\
\text { by activated } \\
\text { sludge }\end{array}$ & $\begin{array}{l}\text { Cefotaxime, Diatrizoate, Fenofibrate, Loratidine, Ketorolac, } \\
\text { Traseolide, Urbason, Paroxethine, Fenoprofen, Erythromycin, } \\
\text { Terbutaline, Amitriptyline, Antipyrine Azithromycin, } \\
\text { Citalopram, Clomipramine, Ifosfamide, Iopamidol, Iopromide, } \\
\text { lincomycin, Sulfamethazine,Nadolol, Fluoxethine, 4- } \\
\text { Dimethylaminoantipyrine (4-DAA), } 4 \text { MMA, acetaminophen, } \\
\text { atenolol, bezafibrate, caffeine, carbamazepine, ciprofloxacin, } \\
\text { codeine, diazepam, fluoxetine, furosemide, gemfibrozil, } \\
\text { Hydrochlorothiazide, ibuprofen, indometachin, ketoprofen, } \\
\text { mepivacaine, metoprolol, metronidazole, N-Acetyl-4-amino- } \\
\text { antiyirine (4-AAA), N-Formyl-4-amino- antiyirine (4-FAA), } \\
\text { nicotine, naproxen, ofloxacin, omeprazole, paraxanthine, } \\
\text { propranolol, ranitidine, salbutamol, sotalol, sulfamethoxazole, } \\
\text { trimethoprim, clarithromycin, cotinine, phenacetin, pravastatin, } \\
\text { salicylic acid, sulfapyridine, benzophenone 3, celestolide, } \\
\text { Ethylhexyl methoxycinnamate, galaxolide, triclosan, Tonalide, } \\
\text { octocrylene, Traseolide }\end{array}$ & $\begin{array}{l}\text { First screen was for } 77 \text { PPCPs, no criteria } \\
\text { presented. Second screen was the } 12 \\
\text { compounds of the first screen that had the } \\
\text { highest concentrations for each therapeutic } \\
\text { category. }\end{array}$ & 23 \\
\hline $\begin{array}{l}\text { Forward osmosis and } \\
\text { membrane distillatio }\end{array}$ & $\begin{array}{l}\text { Synthetic } \\
\text { wastewater and } \\
\text { raw sewage }\end{array}$ & $\begin{array}{l}\text { amitriptyline, diclofenac, carbamazepine, sulfamethoxazoole, } \\
\text { caffeine, trimetoprim, primidone, bezafibrate }\end{array}$ & $\begin{array}{l}\text { PPCPs selected to cover a diverse range of } \\
\text { properties, including charge, volatility, } \\
\text { hydrophobicity, and molecular weight. Also, } \\
\text { MPs were selected are frequently detected in } \\
\text { raw sewage. }\end{array}$ & 48 \\
\hline
\end{tabular}




\begin{tabular}{|c|c|c|c|c|}
\hline $\begin{array}{l}\text { Ozone and ozone } \\
\text { assisted with ultrasound }\end{array}$ & $\begin{array}{l}\text { municipal } \\
\text { wastewater } \\
\text { previously treated } \\
\text { by activated } \\
\text { sludge }\end{array}$ & $\begin{array}{l}\text { acetaminophen, 4-Aminoantipyrine, atorvastatin, bezafibrate, } \\
\text { ciprofloxacin, clarithromycin, clindamycin, diclofenac, enalapril, } \\
\text { erithromycin, gemfibrozil, ibuprofen, ketoprofen, lincomycin, } \\
\text { lorazepam, naproxen, ofloxacin, salycilic acid, sulfamethoxazole, } \\
\text { venlafaxine, valsartan, irbesatan, furosemide, carbamzepine, } \\
\text { gabapentin }\end{array}$ & $\begin{array}{l}\text { Not clearly presented. Mentions target } \\
\text { PPCPs were updated considering } 5 \\
\text { pharmaceuticals widely detected in } \\
\text { wastewaters of the area (out of a total of } 52 \text { ) }\end{array}$ & 49 \\
\hline $\begin{array}{l}\text { Osmotic bioreactor with } \\
\text { reverse osmosis and } \\
\text { conventional membrane } \\
\text { bioreactor with reverse } \\
\text { osmosis }\end{array}$ & $\begin{array}{l}\text { Synthetic } \\
\text { wastewater }\end{array}$ & $\begin{array}{l}\text { Salicylic acid, parcetamol, DEET, caffeine, simazine, ibuprofen, } \\
\text { primidone, naproxen, carbamazepine, gemfibrozil, dilantin, } \\
\text { sulfametoxazole, ketoprofen, atenolol, estrone, estradiol, } \\
\text { Amtriptyline, Androstenedione, Estriol, Testosterone, Triclosan, } \\
\text { Trimethoprim, Etiocholanolone, Androsterone, Diclofenac. 17a- } \\
\text { Ethynylestradiol, Fluoxetine, Triclocarban, Clozapine, } \\
\text { Omeprazole, Hydroxyzine, Enalapril, Risperidone, Simvastatin, } \\
\text { Methotrexate, Verapamil }\end{array}$ & $\begin{array}{l}\text { Fifty PPCPs selected to represent four major } \\
\text { groups of concern in water reuse applications } \\
\text { - pharmaceutically active compounds, } \\
\text { pesticides, steroid hormones and other } \\
\text { endocrine disrupting chemical. Moreover, } \\
\text { mentioned many of these } 50 \text { PPCPs have } \\
\text { been widely reported in the literature in } \\
\text { domestic sewage. }\end{array}$ & 50 \\
\hline $\begin{array}{l}\text { Forward osmosis and } \\
\text { reverse osmosis }\end{array}$ & $\begin{array}{l}\text { Synthetic } \\
\text { wastewater }\end{array}$ & Triclosan and diclofenac & $\begin{array}{l}\text { PPCPs selected because they are ubiquitous } \\
\text { trace organic contaminants in secondary } \\
\text { treated effluent and non-potable recycled } \\
\text { water. Moreover, their physicochemical } \\
\text { properties were essential in their choice, as } \\
\text { authors wanted to provide variable 'solute- } \\
\text { membrane' interactions and subsequent } \\
\text { removal behaviour. }\end{array}$ & 51 \\
\hline $\begin{array}{l}\text { Advanced oxidation } \\
\text { process (not specified) }\end{array}$ & $\begin{array}{l}\text { Reverse osmosis } \\
\text { concentrate } \\
\text { municipal } \\
\text { wastewater } \\
\text { previously treated } \\
\text { by activated } \\
\text { sludge }\end{array}$ & $\begin{array}{l}\text { Gemfibrozil, naproxen, carbamazepine, ofloxacin, erythromycin, } \\
\text { trimethoprm, venlafaxine, atenolol, metoprolol, caffeine, nalidix } \\
\text { acid, iohexol, DEET, sulfamethoxazole, atorvastatin, lovastatin, } \\
\text { enrofloxacin, sulfamethazine, sulfamethizole, sulfamerazine, } \\
\text { cimitidine, farnotidine, ranitidine, iopamidol, iomeprol, } \\
\text { iopromide }\end{array}$ & $\begin{array}{l}\text { PPCPs frequently detected in wastewaters } \\
\text { effluents }\end{array}$ & 52 \\
\hline
\end{tabular}


Daughton and Ruhoy [25] demonstrated the "Matthew Effect" for pharmaceuticals: they present a list of 53 pharmaceuticals of widespread use, of which 16 have never been targeted for monitoring. For such a small sample of 53 (out of over 3000), there is already a $30 \%$ pharmaceuticals ignored on monitoring studies. In addition to them, Oliveira et al. [26] after searching for 185 MP at US WWTP entry and exit points, reported that 13 of the 14 PPCPS not eliminated by conventional WWTP treatment were not included in common PPCPs prioriy lists, suggesting that more PPCPs should be considered as targets. The fourteen were: carisoprodol, clenbuterol, copidogrel, desmethylcitalopram, desmethylvenlafaxine, escitalopram, lamotrigine, meprobamate, norquetiapine, phenobarbital, primidone, temazepam, tramadol. Other than these authors, discussion of Matthew Effect for PPCPs selection is scarce in literature.

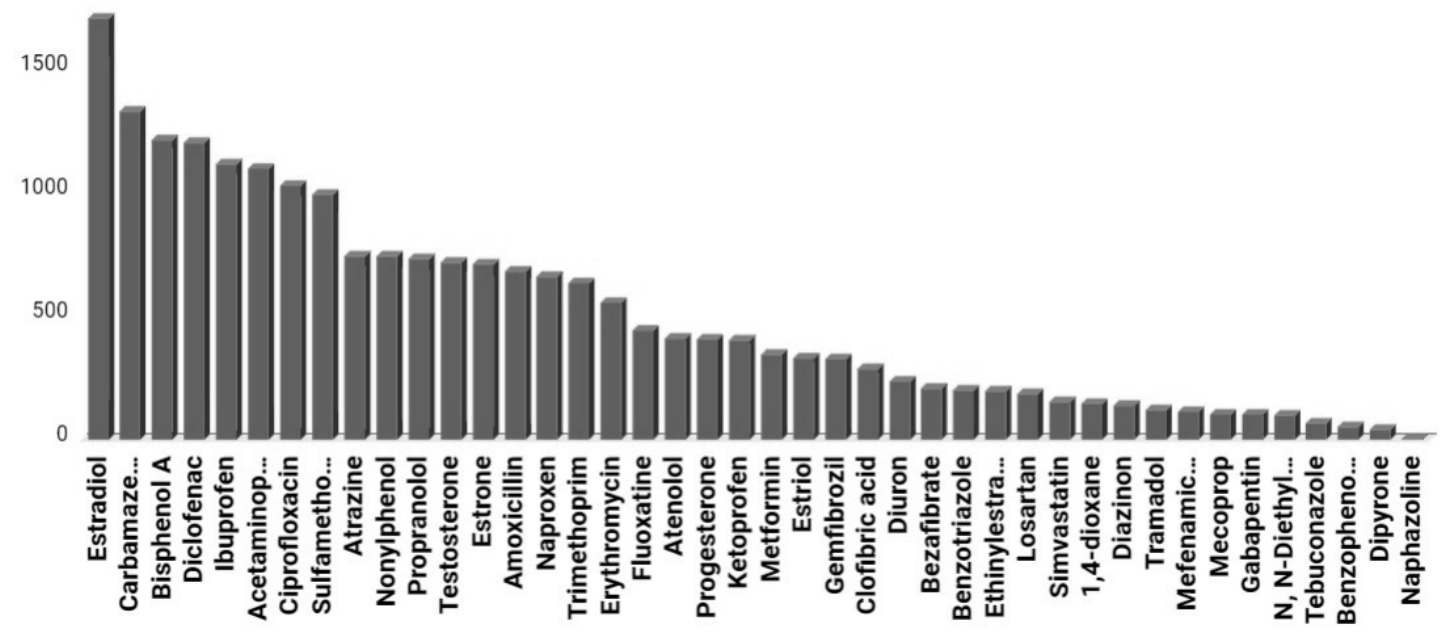

Figure 1. Number of citations by the name of the compound found in SCOPUS database considering environmental context.

Since Fig. 1 was construced by only accounting articles that explicitly in its title, abstract or keywords mention the PPCP, Fig. 1 has a limitation, because many studies in wastewater treatment and environmental monitoring use generic terms such as "PPCPs" in its title and only specify which PPCP within the body of the text. Also, it could grow indefinitely, since there are so many PPCPs. In spite of that, Fig. 1 can already give an overview of how some compounds are extremely mentioned, such as estriol and gemfibrozil, while other much less, like naphazoline and dypirone.

\subsection{Recommendations to Improve Selection Methodologies}

Selection of PPCPs for inclusion in studies is complex, but shall not be based solely on compounds that already common in environmental studies in order to avoid the aforementioned "Matthew effect". Effective mapping of compounds that can be expected to occur more frequently in the environment should be done independently from studies currently available. One strategy is to analyze data from the PPCPs most commonly used by a local population over the years, including Active Pharmaceutical ingredients (APIs) and their main known metabolites; frequency of citing for these APIs and metabolites in environmental studies should also be computed, using databases such as Google Scholar, Web of Science, SCOPUS, EuroPub, PubMed, to name a few. Then an algorithm that crosses both data can be created, looking for APIs and metabolites of great consumption but that correspond to a low number of citations in the bases. From this initial result, refining mechanisms can be included, for example, including data from chronic toxicity, prioritizing among the pre-selected those whose toxicity to aquatic organisms has already been demonstrated. For the construction of these databases and algorithms, considerable computational efforts are necessary, since there are more than 1,000 PPCPs being produced and consumed daily with the number growing every day. Big data analysis will be necessary for such studies. 
Another consideration is that choosing compounds because they belong to different therapeutic classes, as many authors do, is problematic, because the compound may belong to the same class but have different physical-chemical properties and interactions with the environment. A better way would be considering physical-chemical properties directly, since in theory, the selection of a set of few PPCPs that possess properties similar to that of a much larger group allows these PPCPs to be representatives of the larger group. Physical-chemical properties such as polarity, contact angle, water solubility, hydrophobicity and pKa determine the behaviour of PPCPs in the environment and particularly in water and wastewater treatment, and thus will have a major impact on the relevance of a PPCP for selection for a given study.

As previously mentioned, it is essential to consider ecotoxicity information when prioritizing compounds; while there might be an interest, in theory, of removing all anthropogenic compounds from nature, given the huge amount of compounds (even when considering only PPCPs) there is an impossibility of doing so, so it is reasonable to screen only for those who cause proved toxicity to the environment. This has been recommended since 2010 [27]. Ecotoxicity can be assessed by target organisms traditionally used in literature, preferably in chronic toxicity essays that consider not only mortality but also alteration in mobility, reproductive functions, morphology, protein profile or any other alteration that can be concluded it was caused exclusively or at least partially by the presence of PPCPs. But it should be considered that ecotoxicity studies for PPCPs in the environment are still limited, although they have increased in recent years. Therefore many PPCPs have never been evaluated, but they should not be excluded from being selected for future studies as they may have ecotoxicity.

In such cases, a solution is to prioritize persistent (recalcitrant) compounds, because even though recalcitrant molecules are not necessarily toxic to the environment, they increase the odds as they resist microbial attack and consequently accumulate in water, sediments and soil over time. Recalcitrance can be estimated, albeit to a limited extent, based on the category of the compound and the study of its molecular structure and physical-chemical properties, an information readily available for most PPCPs [28]. Dugan [29] for example makes some generalizations: compounds containing one methyl branch are attacked only when the molecule contains a sufficiently long unbranched chain; moreover, the addition of a second methy, group makes the molecule more recalcitrant. Ghosal et al. [30] mentions there is increase in electrochemical stability, persistency and resistance toward biodegradation with an increase in the number of aromatic rings, structural angularity, and hydrophobicity. Alexander [28] presents an extensive review of mechanisms of recalcitrance for synthetic compounds.

\section{Conclusion}

This article presented an overview of criteria currently used by researchers in literature to select Pharmaceuticals and Personal Care Produtcs (PPCPs). It is shown that most used criteria for the selection of PPCPs is their high use by population, widespread presence in the literature, physicochemical characteristics or a choice for PPCPS representing different therapeutic classes, but a considerable number of authors did not mention any criteria for their selection. Moreober, authors seldom mention a clear methodology on how did they organize these criteria on a logical order in a way they can filter the many compounds that fit each criteria until reaching reasonable number while keeping representativity. Certainly the fact that there is still no reference legislation written especially for PPCPs, with the exception of Switzerland, contributes to this fact.

It stands out that a small number of compounds such as carbamazepine, diclofenac, sulfamethoxazole, trimethoprim, gemfibrozil, ibuprofen, naproxen, erythromycin, acetaminophen, 17- $\alpha$-ethinylestradiol (and other synthetic sexual hormones), bisphenol-A, salicylic acid appear in almost all studies considered. Although it is understandable that researchers may want to include some compounds that are already well mapped in the literature, in order to be able to more effectively compare their results with existing published data, this tendency of the few and same compounds to be repeatedly considered raises doubts about the amount of compounds that might be overlooked but are relevant from an environmental point of view. This finding has already been reported but by a few researchers like Daughton [24], Daughton and Ruhoy [25] and Oliveira et al. [26], whom proved that many PPCPs of widespread use have never been mentioned in literature before. These findings suggest there is an 
impending necessity to broaden representativeness of PCPs in studies before it gets to the moment when PPCPs started to be regulated in most countries. It is necessary, by that time, to be sure that all the most relevant PPCPS have been at some point considered, studied and discarded or included.

Some recommendations to improve this selection have been presented; the main one is to cross data from PPCPs most consumed by the population with the frequency of citing of these PPCPs in scientific databases such as Web of Science, Google Scholar and SCOPUS. Priority in research should be given to compounds positioned as of high consumption but with low number of citations in environmental studies. For this, computational efforts involving big data analysis will be necessary, reinforcing the need to face the issue of PPCPs in the environment as an interdisciplinary subject.

Acknowledgments. This study was financed in part by the Coordenação de Aperfeiçoamento de Pessoal de Nível Superior - Brasil (CAPES) - Finance Code 001.

\section{References}

1. Y. Tian and I. Chowdhury, "Adsorption of Selected Pharmaceutical and Personal Care Products with Molybdenum Disulfide and Tungsten Disulfide Nanomaterials", Environ. Eng. Sci. 2019 vol. 36 number 3

2. World Health Organization, Available https://www.who.int/water_sanitation_health/publications/2011/ pharmaceuticals_20110601.pdf(2)

3. Y. Luo, W. Guo, H. H. Ngo, L.D. Nghiem, F.I.Hai, J. Zhang, S. Liang, X.C. Wang, "A review on the occurrence of micropollutants in the aquatic environment and their fate and removal during wastewater treatment", Sci. Total Environ 2014; 473-474 619-641

4. P. Falas, A.Wick, S. Castronovo, J. Habermacher, T.A. Ternes, A. Joss, "Tracing the limits of organic micropollutant removal in biological wastewater treatment", Water Res 2016; 95:240-9

5. E. Gracia-Lor, J.V. Sancho, R. Serrano, F. Hernández, "Occurrence and removal of pharmaceuticals in wastewater treatment plants at the Spanish Mediterranean area of Valencia" Chemosphere 2012; volume 87, Issue 5 Pages 453-462

6. A. Novo, S. André, P. Viana, O.C. Nunes, C.M. Manaia, "Antibiotic resistance, antimicrobial residues and bacterial community composition in urban wastewater", Water Res 2013; Volume 47, Issue 5, Pages 1875-1887

7. J.J.S. Alonso, N.E. Kori, N. Martel-Melián, B. Del Río-Gamero, "Removal of ciprofloxacin from seawater by reverse osmosis", J Environ Manage 2018; 217- Pages 337-345

8. Environmental Protection Agency (EPA), Available https://www.epa.gov/ccl/contaminant-candidate-list-4-ccl$4-0$

9. European Comission (EC), Available http://ec.europa.eu/environment/water/water-dangersub/pdf/ strategic_approach_pharmaceuticals_env.PDF

10. European Comission (EC), Available http://ec.europa.eu/environment/water/water-framework/ priority_substances.htm

11. F. Regan, L. Jones, J. Chapman, "Monitoring of Priority Substances in Waste Water Effluents". 2019 EPA 2019.

12. Environmental Protection Agency (EPA), Available https://www.epa.gov/sites/production/files/2015-10/ documents/method_1694_2007.pdf

13. R. Hochstrat, M. Schärer, H. Bleny, "Elimination of micropollutants - the Swiss approach". 2015. TAPES 2019.

14. M. Al Aukidy, P. Verlicchi, N. Voulvoulis, "A framework for the assessment of the environmental risk posed by pharmaceuticals originating from hospital effluents". Sci Total Environ 2014; 493, 54-64

15. J. Jean, Y. Perrodin, C. Pivot, D. Trepo, M. Perraud, J. Droguet, F. Tissot-Guerraz, F. Locher, "Identification and prioritization of bioaccumulable pharmaceutical substances discharged in hospital effluents". J Environ Manage 2012; 103, 113-121

16. P Voogt, M.L. Janex-Habibi, F. Sacher, L. Puijker, M. Mons, "Development of a common priority list of pharmaceuticals relevant for the water cycle", Water Sci Technol. 2009;59(1):39-46.

17. A.L. Pochodylo and D.E. Helbling, "Emerging investigators series: prioritization of suspect hits in a sensitive suspect screening workflow for comprehensive micropollutant characterization in environmental samples", Environ. Sci.: Water Res. Technol., 2017, vol 3, 54-65 
18. W. Busch, S. Schmidt, R. Kühne, T. Schulze, M. Krauss, R. Altenburg, "Micropollutants in European rivers: A mode of action survey to support the development of effect-based tools for water monitoring", Environ Toxicol Chem. 2016 Aug;35(8):1887-99.

19. P. Carsten von der Ohe, V. Dulio, J. Slobodnik, E. De Deckere, R. Kuhne, R. Ebert, A. Ginebreda, W. De Cooman, G. Schuurmann, W. Brack, "A new risk assessment approach for the prioritization of 500 classical and emerging organic microcontaminants as potential river basin specific pollutants under the European Water Framework Directive", Sci Total Environ 2011; 409: 2064-2077

20. M. Oosterhuis, F. Sacher, T.L. Laak, "Prediction of concentration levels of metformin and other high consumption pharmaceuticals in wastewater and regional surface water based on sales data", Sci Total Environ 2013; Volume 442, Pages 380-388

21. B.G. Katzung BG. Basic and Clinical Pharmacology. Koogan, 2009.

22. V. Karelid, G. Larsson, B. Bjorlenius, "Pilot-scale removal of pharmaceuticals in municipal wastewater: Comparison of granular and powdered activated carbon treatment at three wastewater treatment plants", $J$ Environ Manage 2017; Volume 193 Pages 491-502

23. A.M. Urtiaga, G. Pérez, R. Ibañez, I. Ortiz, "Removal of pharmaceuticals from a WWTP secondary effluent by ultrafiltration/reverse osmosis followed by electrochemical oxidation of the RO concentrate", Desalination 2013; 331: $26-34$

24. C.G. Daughton, "The Matthew Effect and widely prescribed pharmaceuticals lacking environmental monitoring: Case study of an exposure-assessment vulnerability", Sci Total Environ 2014; 466-467 : 315-325

25. C.G. Daughton and I.S. Ruhoy, "Lower-dose prescribing: Minimizing "side effects" of pharmaceuticals on society and the environment", Sci Total Environ 443 (2013) 324-337

26. T.S. Oliveira, M. Murphy, N. Mendola, V. Wong, D. Carlson, L. Waring, "Characterization of Pharmaceuticals and Personal Care products in hospital effluent and waste water influent/effluent by direct-injection LC-MSMS" Sci Total Environ 2015; 518-519 : 459-478

27. T. Ternes and U. von Gunten, Editorial to special issue in Water Research: emerging contaminants in water. Water Res 2010; 44:351.

28. M. Alexander, "Nonbiodegradable and other racalcitrant molecules". Microbial Ecology. 1975 Vol. 2, No. 1 pp. $17-27$

29. P.R. Dugan. Biochemical Ecology of Water Pollution. Plenum Press, 1972.

30. D. Ghosal, S. Ghosh, T.K. Dutta, Y. Ahn, "Current State of Knowledge in Microbial Degradation of Polycyclic Aromatic Hydrocarbons (PAHs): A Review", Front Microbiol. 2016 Aug 31;7:1369 